\title{
PROCESSES OF URBANIZATION IN THE TOWNS OF KARAKALPAKSTAN IN THE XX-TH CENTURY
}

\author{
Esnazarova Zulfiya Baltashevna \\ Candidate of Historical Sciences, Nukus State Pedagogical Institute named after Ajiniyaz
}

Article DOI: https://doi.org/10.36713/epra4547

\begin{abstract}
The article is devoted to the study of the processes of urbanization in the cities and towns of the Republic of Karakalpakstan in the $X X$-th century. There have been defined the reasons of urbanization and distinguished three periods in the processes of urbanization: the study of culture and economics in large centers, spreading of culture in countryside and striving of villages and towns to achieve the level of large cities.
\end{abstract}

KEY WORDS: urbanization, town, village, phenomenon, demography, social, economics, intensive, evolutionary, integration, agroindustry.

\section{DISCUSSION}

The foundation and development of towns in Karakalpakstan was connected with the phenomenon of urbanization of countryside in Central Asia. The development of agriculture in the republic was realized thanks to favorable climatic conditions and water resources.

V.M.Mason investigated the issues of processes of urbanization in the region and found out the following reasons: on the one hand they are realized under the influence of laws of social development, on the other hand, under the influence of holding back going forward. These processes can be studied according to three stages:

First: the study of culture and economics of large centers;

Second: spreading of urban culture in countryside (cultural colonization).

Third: striving of villages and towns for achieving the level of large central cities ${ }^{1}$.

It's natural that trade and commercial relations make influence on the processes of urbanization. The diachronic analysis (from the historical point of view) of urbanization shows the important role of the transcontinental track Great Silk Way that connects East and West. It made an influence on the peoples of Eurasia and became the basis for the intensive development of economics and trade. The situation of the city of Nukus on the cross of the Great Silk Way gives it wide opportunities to communicate with the population of many towns and villages .

A city is considered to be a complex and dynamic phenomena. In the past Nukus was a political, economic center and a fortress "Guardian post", and it was of a great significant, protective and strategic importance. Economic and political development promoted to the formation and development of Nukus as a city. First, the flourishment of trade and handicraft became the basis of the appearance and foundation of Nukus, then the development of industry, transport and functions of government promoted to the fact, that Nukus took a certain honorary place among other large cities. Nukus, being an active form and element in the

\footnotetext{
${ }^{1}$ Masson V.M. Typology of ancient towns and historical process (ancient towns). Materials of the Allunion conference «Culture of Central Asia and Kazakhstan at the epoch of early Middle age». Pedjikent, October 1997). Leningrad, 1977. p.7.
} 


\section{EPRA International Journal of Research and Development (IJRD)}

field of economics, played a great role in the formation of production resources and development of the region in the Republic of Karakalpakstan. It can be seen in the high scientific-technical, social-economic and demographic changes and great influence on the environment. On the basis of these processes the city experienced all forms and ways of urbanization.

In the research we'll focus our attention on the following issues in the study of the capital of the Republic of Karakalpakstan as an economic center situated on the Aral seaside:

- the role of the city in the development of economics and its contribution into the development of the Republic of Karakalpakstan;

the perspectives of the capital in economic development.

Today the provision of urban amenities of the Republic of Uzbekistan and ways of improving this system is considered to be one of the actual issues. This problem should be solved in the regional and urbanization locations. Last time it is recommended to use and include the form of regional extension in the state policy. In the result of the investigation it was found out that towns cannot transfer to a certain category and be independent because of the peculiarities of «planning» economics. It can be seen according to the urban potential in the agro-industrial complex of Karakalpakstan that many towns are usually formed as small towns. We can see it on the example of such towns as Beruniy, Tortkul, Chimbay, Takhtakopir. These towns of middle level are consolidated by the social-economic activisation and improvement of inhabited localities with little population. Such towns as Konirat, Khojeli, Bostan and Elabat are considered to be large towns ${ }^{2}$.

Small towns-villages have an objective basis in the course of their development: traditionally, people living there are provided with the work dealing with agriculture, irrigated lands for growing plants, farms transferring to the industrial method. Methods serve, first of all, to the categories of the town. The urbanization policy in regional localities of such towns corresponds to the agrarian policy of the state. That's why the problems of small towns are solved in the result of social-economic reconstructions in rural inhabited localities of small towns.

Thus, social welfare of the people improves thanks to deepening of market reforms in the agrarian sector of national economy and development of rural infrastructure.

There is a close connection between country sides in Karakalpakstan and foundation of small towns and their service in certain places. Being consolidated by the functions of central places and developing other functions, towns together with places perform their functions in the geoeconomic latitude.

Today the micro-economic stability and development, improvement in the fields of food, fuel energy and transport is one of the actual, important problems of the independent country. Before in the state policy of the most developed countries the issues of the development and improvement of cities-capitals took an honorary place. The issues of high development and increase remained significant problems at the period of "planning" economics. The population increased slowly and gradually. For the last 10 years the population increased only from $2 \mathrm{mln}$. to $2 \mathrm{mln} .200$. Today $10 \%$ of population of Uzbekistan live in Tashkent, it is considered to be the normal situation.

Here is the information about increase and decrease of population in Uzbekistan in the 1991-1999-s.

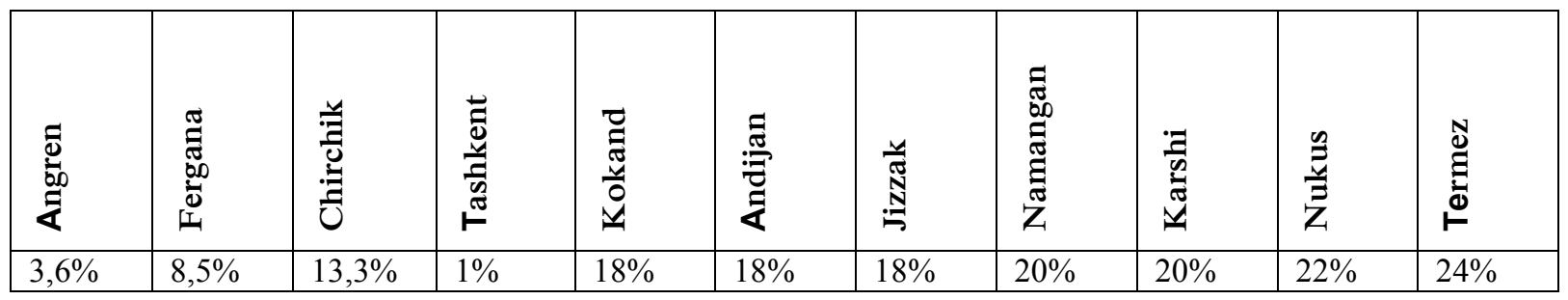

It should be emphasized that towns in Karakalpakstan began to be built in the result of the industrialization and development of light industry and food industry. This social-economic and demographic increase shows a decrease of differences between rural and urban life of the people, countryside and towns. According to the observations there are also other reasons: urbanization, low level of the region' development and others ${ }^{3}$.

\footnotetext{
${ }^{2}$ Ata-Mirzaev O., Genshtke V., Murtazaeva R., Salaev A. Historical-demographic essays of urbanization in Uzbekistan. Tashkent. University, 2002. p.52.

${ }^{3}$ Ata-Mirzaev O., Genshtke V., Murtazaeva R., Salaev A. Historical-demographic essays of urbanization in Uzbekistan. Tashkent. University, 2002. p.57-58.
} 


\section{EPRA International Journal of Research and Development (IJRD)}

Volume: 5 | Issue: 5 | May 2020

- Peer Reviewed Journal

The peculiarities of the region include the situations in the social-economic structure of the republic, necessity of town constructions in the result of modernization. As other cities of Central Asia, the city of Nukus, capital of Karakalpakstan was founded in the result of close links and relations between the peoples of different nationalities and their movements and settlement in the same place.

At the period of totalitarian regime the cotton monoculture brought to the spoiling of land, and in the result of dry the natural environment in Nukus and its surroundings were damaged and spoilt. There was observed a decrease of lands with soil giving rich harvests that brought in its turn to decreasing the degrees of settlement of the people being occupied by agriculture.

Thick density of population in Nukus causes difficulties in the usage of land water resources. Besides, there are some ecological problems connected with improving the sanitary-hygienic relations of highconcentrated harmful things. Such situations increase from year to year, especially on the Aral seaside.

In the result of the research we come to the conclusion that not only in Karakalpakstan but in Central Asia in whole it's difficult to see distincly the differences between the town and countryside. One of the peculiarities of urbanization processes in towns of Central Asia is the accelerated movement of the people to towns. For example, in the city of Nukus we can see the appearance of rural-urban system, such districtsvillages as Kos-kol 1-2-3, Sarancha, Samambay and others gradually, step by step enter the city.

The development of urbanization in Karakalpakstan are characterized by the appearance of large towns. It should be emphasized that the potential of social-economic development and role of the city of Nukus and such large towns as Konirat, Khodjeili are the same like of that one in regional centers.

In seventeen towns of Uzbekistan to 2000 the population was more than 100 in each of them. At average about $58 \%$ constitutes the urban population.

\begin{tabular}{|c|c|c|c|c|c|c|c|c|c|c|c|c|c|c|c|c|}
\hline 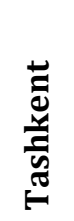 & 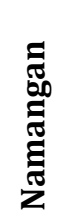 & 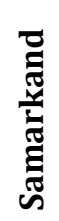 & 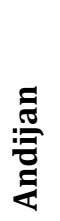 & 递 & $\frac{\mathscr{n}}{\bar{z}}$ & 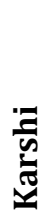 & 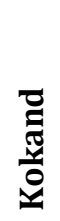 & 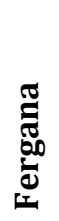 & 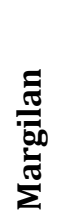 & 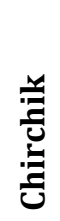 & 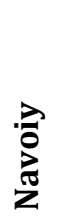 & 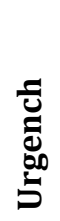 & 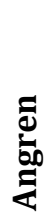 & 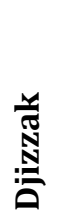 & 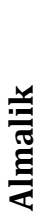 & 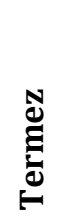 \\
\hline $\begin{array}{l}\dot{\Xi} \\
\vec{\Xi} \\
\vec{\sim}\end{array}$ & 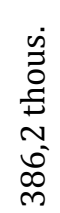 & $\begin{array}{l}\dot{0} \\
\tilde{0} \\
\stackrel{D}{ \pm} \\
\vec{\sigma} \\
\dot{n}\end{array}$ & 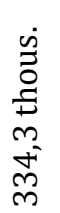 & 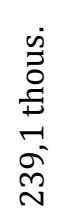 & 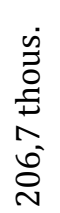 & 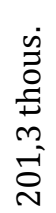 & 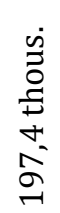 & 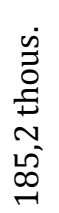 & 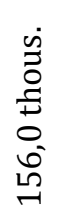 & 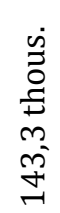 & $\begin{array}{l}\text { gे } \\
\text { +े }\end{array}$ & $\begin{array}{l}\text { ō } \\
\text { mे }\end{array}$ & 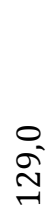 & 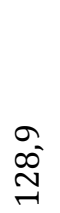 & 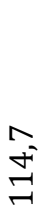 & 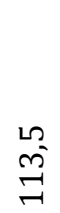 \\
\hline
\end{tabular}

As we can see from the table in the country the same increase of large towns was observed and this fact should be taken into account. The number of towns in Fergana valley-5, in Tashkent region -4, at the Aral seaside-2 (Nukus and Urgench). An increase of the number of population in large and other towns is taken into account in the research of the phenomenon of urbanization in Central Asia.

The investigation of this issue in detail shows the slow development of urbanization processes in Uzbekistan, and it also allows us to feel and see the differences between large and small towns. The peculiarities and distinguishing features of urbanization in Uzbekistan can be defined in the course of the development of regional economics.

Studying generally the urbanization processes in Uzbekistan it should be pointed out that they increase for account of the bases of a great number of small towns.

Last time the agroindustrial character of the national economics give us opportunites to see a thick density of population in rural locality. In the following table we can see the dynamics of density of population in the1989-2000-s 


\section{EPRA International Journal of Research and Development (IJRD)}

Table 3.

\begin{tabular}{|c|c|c|c|}
\hline № & Cities and towns & $\mathbf{1 9 8 9}$ & $\mathbf{2 0 0 0}$ \\
\hline 1. & Nukus & 168,5 thousand & 206,7 thousand \\
\hline 2. & Khodjeili & 59,2 thousand & 69,2 thousand \\
\hline 3. & Takhiatash & 42,8 thousand & 48,6 thousand \\
\hline 4. & Tortkul & 35,9 thousand & 47,3 thousand \\
\hline 5. & Beruniy & 37,3 thousand & 35,2 thousand \\
\hline 6. & Konirat & 29,4 thousand & 33,1 thousand \\
\hline 7. & Chimbay & 27,1 thousand & 30,5 thousand \\
\hline 8. & Mangit & 23,1 thousand & 11,4 thousand \\
\hline 9. & Khalkabad & 9,1 thousand & 13,6 thousand \\
\hline 10. & Moinak & 12,0 thousand & 12,6 thousand \\
\hline 11. & Shumanai & 10,4 thousand & 13,1 thousand \\
\hline 12. & Bostan & 8,4 thousand & \\
\hline
\end{tabular}

In the national system of towns the city of Nukus of Karakalpakstan plays a leading role and the population size in it is three times more than in Khodjeili, seven times more than in Konirat, Chimbay and Mangit. These indicators show that according to population size and social-economic development the capital of Karakalpakstan stands in the first place comparatively with the towns situated at the Aral seaside.

That's why in future performing its functions as a capital, it will take a place after Tashkent, the capital of Uzbekistan, and it will develop the leading role in service and financial functions. The functioning and service of the international airport, international stations situated at the cross of the Great Silk Way and the construction of other objects will strengthen the position of political development of sovereign Republic of Karakalpakstan.

If we compare the poles of increase in regional centers, the development of town-villages (villages of urban type) in large cities and towns as Nukus, Khodjeili, Tortkul, Konirat and others are characterized by distinguishing features.

\section{Dynamics of increasing urban population in the1989-2000-s on the Aral seaside. The Republic of Karakalpakstan. Town-villages.}

Table 4.

\begin{tabular}{|c|c|c|c|}
\hline № & Town-villages & $\mathbf{1 9 8 9}$ & $\mathbf{2 0 0 0}$ \\
\hline 1. & Altinkol & 20,4 thousand & 24,0 thousand \\
\hline 2. & Kizketken & 16,6 thousand & 23,8 thousand \\
\hline 3. & Takhtakopir & 14,8 thousand & 17,2 thousand \\
\hline 4. & Pristan & 13,0 thousand & 15,6 thousand \\
\hline 5. & Kegeili & 10,7 thousand & 13,0 thousand \\
\hline 6. & Kanlikol & 7,2 thousand & 9,9 thousand \\
\hline 7. & Akmangit & 6,0 thousand & 8,1 thousand \\
\hline 8. & Vodnik & 5,2 thousand & 6,1 thousand \\
\hline 9. & Karaozek & 10,4 thousand & 4,5 thousand \\
\hline 10. & Karakalpakia & 3,0 thousand & 4,1 thousand \\
\hline 11. & Jaslik & 2,6 thousand & 4,1 thousand \\
\hline 12. & Jumirtau & 0,1 thousand & 3,5 thousand \\
\hline 13. & Kazanketken & 2,1 thousand & 2,8 thousand \\
\hline 14. & Karatau & 0,1 thousand & 1,0 thousand \\
\hline 15. & Aksholpan & 0,5 thousand & 0,7 thousand \\
\hline 16. & South Ustuyrt &
\end{tabular}

The natural resources of the mountain Sultan Wayis and a village Karatau situated there consolidated the position of Nukus as a capital of Karakalpakstan not only on the Aral seaside but all over Uzbekistan.

As it has been mentioned above, there are many enterprises and establishments equipped with modern technologies in Nukus, Khodjeili, Takhiatash and Khalkabad, and in future it is planned to develop and increase

\footnotetext{
${ }^{4}$ Baz Karatau, Kizketken, Pristan.
} 


\section{EPRA International Journal of Research and Development (IJRD)}

their number in Nukus, Khodjeili, Takhiatash, Akmangit, Kizketken, Karatau, Pristan, Khalkabad and other places of Karakalpakstan.

Thus, all the towns and villages in Karakalpakstan cannot be developed at the same time and at the same degree, and it is necessary to select them from regional hierarchy taking into account their potential as centers. These centers for Nukus are such towns as Khodjeili, Takhiatash, Akmangit, Khalkabad with the villages Karatau, Pristan, Kizketken, they all make the requirements. We can see these characteristic features in the leading position of the capital of Karakalpakstan and in the economics of the Aral seaside.

Studying the issues of urbanization in towns and villages of Karakalpakstan, we compared them with the data got in the result of the investigation of the dynamics of increasing towns and villages in Khorezm region.

Dynamics of increasing towns and villages of urban type in 1926-2000 in Khorezm region (in account of one thousand people)

\begin{tabular}{|c|c|c|c|c|c|c|c|c|}
\hline № & Towns & $\mathbf{1 9 2 6}$ & $\mathbf{1 9 3 9}$ & $\mathbf{1 9 5 9}$ & $\mathbf{1 9 7 0}$ & $\mathbf{1 9 7 9}$ & $\mathbf{1 9 8 9}$ & $\mathbf{2 0 0 0}$ \\
\hline 1. & Urgench & 5,3 & 22,5 & 43,8 & 76,2 & 98,0 & 126,4 & 139,2 \\
\hline 2. & Khiva & 20,3 & 14,4 & 17,5 & 24,1 & 30,4 & 39,2 & 48,8 \\
\hline 3. & Pitnyak & - & - & - & - & 8,6 & 12,2 & 15,7 \\
\hline
\end{tabular}

It can be seen from the table that the urbanization processes according to population increase develop meanly in Khorezm region. Urgench and towns Khiva, Khazarasp, situated near it, are considered to be the centers of tourism. Besides there is an international airport and many objects of automobile construction there. Despite these facts these towns fall behind Nukus according to population increase.

Dynamics of increasing towns and villages of urban type in 1926-2000 in Khorezm region (in account of one thousand people)

\begin{tabular}{|c|c|c|c|c|c|c|c|c|}
\hline № & Village ofurban type & $\mathbf{1 9 2 6}$ & $\mathbf{1 9 3 9}$ & $\mathbf{1 9 5 9}$ & $\mathbf{1 9 7 0}$ & $\mathbf{1 9 7 9}$ & $\mathbf{1 9 8 9}$ & $\mathbf{2 0 0 0}$ \\
\hline 1. & Khamza & - & - & - & - & - & 28,8 & 31,7 \\
\hline 2. & Gurlen & - & - & - & - & - & 19,5 & 21,6 \\
\hline 3. & Kushkupir & - & - & - & - & - & 11,7 & 15,6 \\
\hline 4. & Khazarasp & - & - & - & - & - & 12,2 & 15,7 \\
\hline 5. & Shavat & - & - & - & - & 0,8 & 19,1 & 14,6 \\
\hline 6. & Chalish & - & - & - & - & 3,1 & 5,0 & 5,9 \\
\hline 7. & Yangibazar & - & - & - & - & - & 4,5 & 5,9 \\
\hline
\end{tabular}

The agro-industrial character of villages of urban type, an important role of the national economics and agriculture in the urbanization processes are realized inside the region. If we compare towns in Khorezm region with Nukus, they fall behind according to population increase and size. Comparatively with them Nukus has some advantages: it has close connections with Uchkuduk, Navoiy, Sultan Wayis, and the railway NukusKungrad plays an important role as a caravanserai. The influence of urbanization processes on Nukus is in the following: it opens a way to the appearance and development of large towns on the Aral seaside. We can the same situation on the example of Tashkent, Margilan, Samarkand.

Thus, being of urban type according to agro-melioration form, really such villages are of rural-urban type, and there are all opportunities to develop agro-industrial complexes and branches there. That's why, they play a great role in the development of national economics in the agrarian sector by acceleration and improvement of relations and links between town and village.

The capital of Karakalpakstan Nukus enters the oasis of capital regions having irrigated lands cultivated on the basis of agro-melioration and situated geographically on the Aral seaside. These suitable geographical situation, natural conditions promote to the improvement of people's level of life and welfare. Urbanization consists of internal contradictions and complex structures. They can be proved by increase of towns, movement and settlement. Taking into account the development of urbanization on the Aral seaside by evolutionary ways, today we observe the development the agro-industrial integration and increase of small towns.

It should be pointed out the great significance and role of Nukus in solving the issues of arrangement and reconstruction in urbanization processes in geopolitical regions.

Many changes taken place in the country: transition to market economy, many-structured system of economy, consolidation of mutual cooperation with foreign companies, the strategy of developing urbanization in Uzbekistan give their good results today. That's why the issues of social development in villages and kishlaks 


\section{EPRA International Journal of Research and Development (IJRD)}

should be investigated taking into account the state and relationship of both: town and village. In this relationship there are some situations that show the differences between town and village. Nukus cannot be responsible for an accelerated increase of urbanization processes in the city.

Thus, it becomes clear why particularly Nukus, situated on the Aral seaside with the developed economy, was assigned as the capital of the Republic of Karakalpakstan.

\section{Dynamics of population in the cities and towns of Karakalpakstan}

\begin{tabular}{|c|c|c|c|}
\hline \multicolumn{4}{|c|}{ in 1926-19395 } \\
\hline No & Cities and towns & In $\mathbf{1 9 2 6}$ & In 1939 \\
\hline 1. & Tortkul & 4,1 thousand & 19,6 thousand \\
\hline 2. & Nukus & 3,4 thousand & 14,0 thousand \\
\hline 3. & Khodjeili & 3,0 thousand & 11,4 thousand \\
\hline 4. & Chimbay & 5,4 thousand & 8,5 thousand \\
\hline 5. & Konirat & 4,2 thousand & 4,9 thousand \\
\hline 6. & Moinak & 1,9 thousand & 2,9 thousand \\
\hline
\end{tabular}

Thus, Nukus, within 13 years before the war, was considered to be one of the cities among other towns taking the first place according to the development in all spheres of life, including the population increase. According to population size it was in the second place after Tortkul.

The comparative analysis and study of population size in Nukus comparatively with other cities and towns of Uzbekistan in 1926-1939 shows the place of Nukus among them.

Dynamics of population size in the city of Nukus in 1926-1939 comparatively with other cities and towns of Uzbekistan

\begin{tabular}{|c|c|c|c|}
\hline No & Cities and towns & In 1926 & In 1939 \\
\hline 1. & Tashkent & 314,0 thousand & 556,1 thousand \\
\hline 2. & Samarkand & 105,2 thousand & 136,3 thousand \\
\hline 3. & Andijan & 73,5 thousand & 84,7 thousand \\
\hline 4. & Namangan & 73,6 thousand & 79,5 thousand \\
\hline 5. & Bukhara & 46,7 thousand & 50,3 thousand \\
\hline 6. & Margilan & 44,3 thousand & 46,0 thousand \\
\hline 7. & Fergana & 14,3 thousand & 38,6 thousand \\
\hline 8. & Kattakurgan & 14,5 thousand & 25,9 thousand \\
\hline 9. & Urgench & 10,2 thousand & 22,5 thousand \\
\hline 10. & Kokand & 3,2 thousand & 12,7 thousand \\
\hline 11. & Urgut & 3,7 thousand & 16,5 thousand \\
\hline 12. & Yangiyul & 13,2 thousand & 16,2 thousand \\
\hline 13. & Karshi & 14,4 thousand & 15,8 thousand \\
\hline 14. & Chist & 20,3 thousand & 14,4 thousand \\
\hline 15. & Khiva & 3,4 thousand & 14,0 thousand \\
\hline 16. & Nukus & &
\end{tabular}

The first leader of the Republic of Karakalpakstan K.Kamalov contributed much into the development of the city of Nukus. Nukus became a political-economic, scientific, educational, cultural and spiritual center. The following persons worked as a major of the city of Nukus: Sm.Iskenderov, I.Sultanov, N.Turintaev, K.Khudaibergenov, A.Begmanov, Sh.Paluanov, M.Yusupov, R.Babanazarov, J.Abdimuratov, A.Kunnazarov, the pupils of K.Kamalov -L.Burd, A.Yakushin, S.Nurkhojaev, B.Bekturdiev, A.Asanov, E.Dauletmuratov, Sh.Usnatdinov, A.Ametov and I.Khalmuratov ${ }^{6}$.

\footnotetext{
${ }^{5}$ Central State Archive of the Republic of Karakalpakstan. f. 322,reg. 1, d.87, 1.19; f.324, reg.1, d.4, 1.3; 1.5, 1.3.

${ }^{6}$ Koshanov B.A. Stories about the capital. It is rightly called «the main» // Vesti Karakalpakstana. Nukus, 2002, October 15.
} 


\section{EPRA International Journal of Research and Development (IJRD)}

Volume: 5 | Issue: 5 | May 2020

- Peer Reviewed Journal

Academician S.K.Kamalov in his works emphasizes that a frequent change of the city major made a negative influence on the development of infrastructure of the city.

We've studied an increase of population size in the capital of Karakalpakstan Nukus comparatively with the population of other cities and towns of Uzbekistan for 30 years and received the following data.

Dynamics of population size in the city of Nukus in 1959-1989 comparatively with other cities and towns of Uzbekistan ( 1000 people)

\begin{tabular}{|c|c|c|c|c|c|}
\hline № & Cities and towns & $\mathbf{1 9 5 9}$ & $\mathbf{1 9 7 0}$ & $\mathbf{1 9 7 9}$ & $\mathbf{1 9 8 9}$ \\
\hline 1. & Tashkent & 926,7 & 1384,5 & 1754,5 & 2053,7 \\
\hline 2. & Samarkand & 196,5 & 266,8 & 470,1 & 364,0 \\
\hline 3. & Namangan & 123,5 & 175,3 & 226,6 & 304,4 \\
\hline 4. & Andijan & 130,9 & 188,0 & 229,7 & 290,5 \\
\hline 5. & Bukhara & 69,3 & 111,0 & 184,8 & 222,2 \\
\hline 6. & Fergana & 80,2 & 111,3 & 173,0 & 198,3 \\
\hline 7. & Kokand & 105,1 & 133,1 & 151,5 & 179,5 \\
\hline 8. & Nukus & 39,1 & 74,1 & 106,9 & 168,5 \\
\hline
\end{tabular}

In conclusion, it should be pointed out that the issues of studying urbanization processes are considered to be significant, actual problems in the science of history, and they deserve further research. That's why before the study of the origin, history and development of a city or a town it is recommended to start with the study of urbanization processes there.

\section{REFERENCES}

1. Ata-Mirzaev O., Genshtke V., Murtazaeva R., Salaev A. Historical-demographic essays of urbanization in Uzbekistan. Tashkent. University, 2002.

2. Koshanov B.A. Stories about the capital. It is rightly called «the main» // Vesti Karakalpakstana. Nukus, 2002, October 15.

3. Masson V.M. Typology of ancient towns and historical process (ancient towns). Materials of the Allunion conference «Culture of Central Asia and Kazakhstan at the epoch of early Middle age». Pedjikent, October 1997). Leningrad, 1977.

4. Materials from the Central State Archive of the Republic of Karakalpakstan for 1926-1939. 